\title{
Estimation of Critical Nitrogen Concentration Based on Leaf Dry Matter in Drip Irrigation Spring Maize Production in Northern China
}

biao jia ( $\sim$ jiabiao2008@163.com )

Ningxia University https://orcid.org/0000-0003-2512-3819

Jiangpeng Fu

Ningxia University

Huifang Liu

Ningxia University

Zhengzhou Li

Ningxia University

Yu Lan

Ningxia University

Xue Wei

Ningxia University

Yongquan Zhai

Ningxia University

Bingyuan Yun

Ningxia University

Jianzhen Ma

Ningxia University

Hao Zhang

Ningxia University

\section{Research Article}

Keywords: Maize, Leaf dry matter (LDM), Critical $\mathrm{N}$ concentration (Nc), Leaf $\mathrm{N}$ concentration (LNC), Nitrogen nutrition index (NNI).

Posted Date: November 12th, 2021

DOI: https://doi.org/10.21203/rs.3.rs-1043083/v1

License: (a) (i) This work is licensed under a Creative Commons Attribution 4.0 International License.

Read Full License 


\section{Abstract}

Background: The application of nitrogen $(\mathrm{N})$ fertilizer not only increases crop yield but also improves the $\mathrm{N}$ utilization efficiency. The critical $\mathrm{N}$ concentration $\left(\mathrm{N}_{\mathrm{c}}\right)$ can be used to diagnose crops $\mathrm{N}$ nutritional status. The $\mathrm{N}_{\mathrm{c}}$ dilution curve model of maize was calibrated with leaf dry matter (LDM) as the indicator, and the performance of the model for diagnosing maize $\mathrm{N}$ nutritional status was further evaluated. Three field experiments were carried out in two sites between 2018 and 2020 in Ningxia Hui Autonomous Region with a series of $\mathrm{N}$ levels (application of $\mathrm{N}$ from 0 to $450 \mathrm{~kg} \mathrm{~N} \mathrm{ha}^{-1}$ ). Two spring maize cultivars, i.e., Tianci19 (TC19) and Ningdan19 (ND19), were utilized in the field experiment.

Results: The results showed that a negative power function relationship existed between LDM and leaf $\mathrm{N}$ concentration ( $L N C)$ for spring maize under drip irrigation. The $\mathrm{N}_{\mathrm{C}}$ dilution curve equation was divided into two parts: when the LDM $<1.11 \mathrm{t} \mathrm{ha}^{-1}$, the constant leaf $\mathrm{N}_{\mathrm{c}}$ value was $3.25 \%$; and when LDM $>1.11 \mathrm{t}$ $\mathrm{ha}^{-1}$, the $\mathrm{N}_{\mathrm{c}}$ curve was $3.33^{*} \mathrm{LDM}^{-0.24}$.

Conclusion: The LDM based $\mathrm{N}_{\mathrm{c}}$ curve can well distinguish data the $\mathrm{N}$-limiting and non-N-limiting $\mathrm{N}$ status of maize, which was independent with maize varieties, growing seasons and stages. Additionally, the $\mathrm{N}$ nutrition index ( $\mathrm{NNI}$ ) had a significant linear correlation with the relative leaf dry matter (RLDM). This study revealed that the LDM based $\mathrm{N}_{\mathrm{c}}$ dilution curve could accurately identify spring maize $\mathrm{N}$ status under drip irrigation. $\mathrm{NNI}$ can thus, be used as a robust and reliable tool to diagnose $\mathrm{N}$ nutritional status of maize.

\section{Introduction}

Nitrogen $(\mathrm{N})$ is a key element for maintaining crop growth [1]. Under $\mathrm{N}$ deficiency, an increase of $\mathrm{N}$ application can dramatically stimulate the growth of crops and maintain a good grain yield [2]. However, the applied $\mathrm{N}$ in the soil cannot be fully absorbed by the crop, and consequently, about $60 \%$ of the $\mathrm{N}$ fertilizer is lost through ammoniation, nitrification, denitrification, leaching, and runoff [3]. The $\mathrm{N}$ utilization efficiency has become an important factor restricting sustainable development of agricultural production, since $\mathrm{N}$ utilization efficiency is generally low as a result of excessive $\mathrm{N}$ application for maintaining high grain yield $[4,5]$. The major challenge is how to achieve optimum water-fertilizer management, and obtain a continuous increase in maize production and efficiency in intensive planting $[6,7]$. At different growth stages of maize, optimizing its $\mathrm{N}$ application rate is especially helpful to further improve maize yield and quality $[8,9]$.

Diagnosis of $\mathrm{N}$ nutrition in crops mainly includes the measurement of chlorophyll using chlorophyll meter [10], spectral diagnosis [11], remote sensors [12], as well as image processing [13]. One of the common disadvantages of these methods is that there are large variations in the results obtained especially under luxury absorption [14, 15]. Greenwood et al. (1991) [15] summarized the characteristics of crop growth and $\mathrm{N}$ absorption and proposed the concept of critical $\mathrm{N}$ concentration $\left(\mathrm{N}_{\mathrm{c}}\right)$, which is the minimum $\mathrm{N}$ 
required for the maximum crop growth. $\mathrm{N}_{\mathrm{c}}$ has received significant attention from numerous researchers related to reliable $\mathrm{N}$ diagnosis with sufficient accuracy, and can thus, be used as an index to evaluate the crop $\mathrm{N}$ nutritional status of crops. Plant dry matter (PDM) based $\mathrm{N}_{\mathrm{c}}$ dilution curves have been successfully constructed and applied in rice $[14,16,17]$, wheat $[18,19]$, and other crops [20]. However, some previous reports show that $\mathrm{N}_{\mathrm{c}}$ dilution curves may vary with environmental conditions, crops, and varieties [21, 22]. Therefore, a robust $\mathrm{N}_{\mathrm{C}}$ dilution curve is especially important for diagnosing $\mathrm{N}$ requirements during the growth of specific crops.

Maize (Zea mays L.) is a globally main crop. Growth and yield of maize are significantly affected by the application of fertilizers, especially for $\mathrm{N}$. Previous studies have reported calibrated $\mathrm{N}_{\mathrm{c}}$ curves model for maize in different regions using plant dry matter (PDM) [21, 23]. Leaves are the main tissues and organs of maize, while the $\mathrm{N}_{\mathrm{c}}$ dilution curves model is also varied with tissues and organs [24]. Besides, leaves are extremely sensitive to $\mathrm{N}$ nutritional status. For instance, the leaf dry matter (LDM) and $\mathrm{N}$ of maize generally increase with increased $\mathrm{N}$ application. However, when $\mathrm{N}$ was applied above a certain dosage, LDM does not increase but the $\mathrm{N}$ concentration continues to increase [22]. With maize growth, the dry matter accumulation in leaves increases, but the $\mathrm{N}$ concentration decreases [22]. Therefore, the leaves $\mathrm{N}$ concentration (LNC) can be used as an important index for evaluating the status of crop growth. For instance, LDM based $\mathrm{N}_{\mathrm{c}}$ curve has been successfully established and applied in several main crops, such as rice [25], and winter wheat [26]. However, LDM based $N_{c}$ curve model in maize has not been calibrated under the integrated technology of water and fertilizer. Therefore, this study aimed (1) to calibrate and validate LDM based $\mathrm{N}_{\mathrm{c}}$ dilution curve in maize, (2) to compare the validated model with other crops $\mathrm{N}_{\mathrm{c}}$ curve models and to evaluate its reliability in spring maize, and (3) to offer a novel method for precisely managing $\mathrm{N}$ fertilizer application in spring maize cultivated under drip irrigation conditions.

\section{Materials And Methods}

\section{Field experiment design:}

Three experiments were carried out in two experimental sites, Pingjipu $\left(38^{\circ} 25^{\prime} \mathrm{N}, 106^{\circ} 1^{\prime} \mathrm{E}\right)$ and Yongning $\left(38^{\circ} 13^{\prime} \mathrm{N}, 106^{\circ} 14^{\prime} \mathrm{E}\right)$ in 2018,2019 , and 2020 in Ningxia Hui Autonomous Region of China. The spring maize cultivars were, Tianci19 (TC19) and Ningdan19 (ND19). Six N fertilizer application rates included 0 (N0), 90 (N1), 180 (N2), 270 (N3), 360 (N4), and $450 \mathrm{~kg} \mathrm{ha}^{-1}$ (N5). A randomized complete block design with three replicate was used in the experimental plots. Each plot $(15 \mathrm{~m} \times 4.5 \mathrm{~m})$ had eight rows of spring maize, with $40 \mathrm{~cm}-70 \mathrm{~cm}$ row spacing and $20 \mathrm{~cm}$ distance between each hill within each row, following typical planting of spring maize. The plant density reached 90,000 plants ha $^{-1}$. The basic soil properties are shown in Table 1, including sowing and harvesting date information. 
Table 1

Soil properties $(0-60 \mathrm{~cm}$ depth) in the experimental fields

\begin{tabular}{|c|c|c|c|c|c|c|c|}
\hline \multirow[t]{2}{*}{ Parameter } & \multirow[t]{2}{*}{ Units } & \multicolumn{6}{|c|}{ Experiments } \\
\hline & & \multicolumn{2}{|c|}{ Experiment 1} & \multicolumn{2}{|c|}{ Experiment 2} & \multicolumn{2}{|c|}{ Experiment 3} \\
\hline Year & & 2018 & & 2019 & & 2020 & \\
\hline Site & & Pingjipu & Yongning & Pingjipu & Yongning & Pingjipu & Yongning \\
\hline Cultivar & & TC19 & ND19 & TC19 & ND19 & TC19 & ND19 \\
\hline $\mathrm{pH}$ value & & 7.82 & 8.53 & 7.98 & 8.44 & 7.76 & 8.57 \\
\hline $\begin{array}{l}\text { Organic } \\
\text { matter }\end{array}$ & $\mathrm{g} \mathrm{kg}^{-1}$ & 14.83 & 10.56 & 11.45 & 8.07 & 12.82 & 14.83 \\
\hline Total N & $\mathrm{g} \mathrm{kg}^{-1}$ & 0.92 & 0.96 & 0.8 & 0.98 & 0.75 & 0.92 \\
\hline Available N & $\begin{array}{l}\mathrm{mg} \\
\mathrm{kg}^{-1}\end{array}$ & 37.81 & 40.23 & 37.42 & 40.47 & 36.82 & 39.44 \\
\hline Available P & $\begin{array}{l}\mathrm{mg} \\
\mathrm{kg}^{-1}\end{array}$ & 20.63 & 18.96 & 19.04 & 18.33 & 19.37 & 20.63 \\
\hline Available K & $\begin{array}{l}\mathrm{mg} \\
\mathrm{kg}^{-1}\end{array}$ & 109.17 & 108.92 & 102.53 & 106.25 & 105.31 & 111.25 \\
\hline Sowing date & & $20 / 4$ & $24 / 4$ & $26 / 4$ & $22 / 4$ & $28 / 4$ & $20 / 4$ \\
\hline $\begin{array}{l}\text { Harvesting } \\
\text { date }\end{array}$ & & $22 / 9$ & $20 / 9$ & $16 / 9$ & $18 / 9$ & $18 / 9$ & $22 / 9$ \\
\hline
\end{tabular}

The integrated technology of water and fertilizer was adopted in field experiments. The total irrigation amount applied during the maize growing season in each plot was $400 \mathrm{~mm}$, including 20, 100, 140, 120, and $20 \mathrm{~mm}$ at the seedling, jointing-bell, tasseling-silk, filling, and maturity stage, respectively. Urea dissolved in drip irrigation was applied as $\mathrm{N}$ fertilizer, with $10 \%, 45 \%, 20 \%$, and $25 \%$ of the $\mathrm{N}$ applied at seedling, jointing-bell, tasseling-silk, and filling stage, respectively. And $138 \mathrm{~kg}$ potassium dihydrogen $\left(\mathrm{P}_{2} \mathrm{O}_{5} \mathrm{ha}^{-1}\right)$ and $120 \mathrm{~kg}$ potassium sulfate $\left(\mathrm{K}_{2} \mathrm{O} \mathrm{ha}{ }^{-1}\right)$ were applied as the phosphorus and potassium fertilizer for each plot. Other management followed the practices of local farmers.

\section{Sampling and measurement}

Three spring maize plants with uniform growth were randomly selected from each plot at the fourth leaf collar (V4), the sixth leaf collar (V6), the tenth leaf collar (V10), the twelfth leaf collar (V12), tasseling stage (VT) and silking stage (R1). The plants were separated into stems and leaves. Plant tissues were oven-dried at $105^{\circ} \mathrm{C}$ for $30 \mathrm{~min}$ and then at $80^{\circ} \mathrm{C}$ until reaching a constant weight. All sampled leaves were weighted to calculate the LDM and stored in hermetic bags for the downstream chemical analysis. The leaves $\mathrm{N}$ content was measured by using the micro-Kjeldahl method [27]. 


\section{Critical Nitrogen Dilution Curve}

The critical nitrogen dilution $\left(\mathrm{N}_{\mathrm{c}}\right)$ was calculated following the method reported by Justes et al. [28]. A typical power-law function was adopted to regress the correlation between $\mathrm{N}_{\mathrm{c}}$ and LDM. The two-year data (i.e., experiment 1 and 2) were used to calibrate the $\mathrm{N}_{\mathrm{c}}$ model for the two spring maize cultivars. The calibrated curve model was further validated by an independent dataset from experiment 3. $\mathrm{N}_{\mathrm{c}}$ was derived from the equation described by Plénet and Lemaire [29]:

$\mathrm{N}_{\mathrm{C}}=a \operatorname{LDM}^{-b}(1)$

Where $\mathrm{N}_{\mathrm{C}}$ means the $\mathrm{N}_{\mathrm{c}}$ concentration concentration (\%), LDM represents the leaf dry matter $\left(\mathrm{t} \mathrm{ha}{ }^{-1}\right), a$ indicates the $\mathrm{N}_{\mathrm{c}}$ concentration concentration when LDM equalts to $1 \mathrm{t} \mathrm{ha}^{-1}$, while $b$ is the statistical parameter controlling the slope of the curve, representing the ratio of the relative dry matter accumulation rate to the relative $\mathrm{N}$ content accumulation rate.

\section{Nitrogen Nutrition Index}

The N nutrition index (NNI) was derived from the equation reported by Plénet and Lemaire [29]:

$$
\mathrm{NNI}=\mathrm{LNC} / \mathrm{N}_{\mathrm{C}}
$$

2

$\mathrm{NNI}=1,>1$, and $<1$ mean plant $\mathrm{N}$ nutritional status is optimal, excessive, and deficient, respectively.

\section{Relative Ldm}

Relative LDM (RLDM) was calculated by dividing the LDM to the maximum LDM at each growth stage. The following equation was used:

$$
\mathrm{RLDM}_{\mathrm{i}}=\mathrm{LDM}_{\mathrm{i}} / \mathrm{LDM}_{\max } \quad\left(0<\mathrm{RLDM}_{\mathrm{i}}<1\right)
$$

where $R L D M_{i}$ is the relative leaf dry matter within growth stage $i, L D M_{i}$ is the measured leaf dry matter within growth stage $\mathrm{i}\left(\mathrm{t} \mathrm{ha}^{-1}\right)$, and $\mathrm{LDM}_{\max }$ represents the maximum leaf dry matter at each growth stage $\left(\mathrm{tha}^{-1}\right)$.

\section{Statistical Analysis}

ANOVA was used to analyze the significant difference between LDM and LNC in different nitrogen fertilizer application rates. Means were determined using the least significant difference at the $P<0.05$ 


\section{Results}

\section{The dynamic change in the status of both spring maize cultivar's LDM and LNC}

The leaf dry matter (LDM) of both spring maize cultivars increased as the growth stage increased in all the six $\mathrm{N}$ fertilizer application rates. The increase followed an S-shaped pattern (Fig. 1). The LDM of TC19 and ND19 ranged from 0.32 to $4.06 \mathrm{t} \mathrm{ha}^{-1}$ (Fig. 1a) and 0.23 to $3.73 \mathrm{t} \mathrm{ha}^{-1}$ (Fig. 1b) in 2018, and from 0.39 to $4.30 \mathrm{t} \mathrm{ha}^{-1}$ (Fig. 1C) and 0.34 to $3.97 \mathrm{t} \mathrm{ha}^{-1}$ (Fig. 1d) in 2019, respectively. Significant differences in LDM were observed from N0 to N3 rates in both 2018 and 2019. However, no significant differences in LDM of both maize cultivars were observed between N4 and N5 rates.

The leaves nitrogen content (LNC) of both spring maize cultivars also increased as the growth stage increased in all the six $\mathrm{N}$ fertilizer application rates. In general, for all the crop growth stages, decrease of LNC accompanied by an increase in LDM (Fig. 2). The LNC of TC19 and ND19 ranged between 1.38$3.74 \%$ and $1.85-3.53 \%$ in 2018 (Fig. 2a, b), and between $1.42-3.61 \%$ and $1.43-3.48 \%$ in 2019 (Fig. 2c, d), respectively. The LNC of the same cultivar had a similar variation tendency.

\section{Calibration Of $\mathbf{N}$ Curves}

The $\mathrm{N}_{\mathrm{c}}$ values were calculated from V6 to R1 for the two spring cultivars (TC19 and ND19) using experimental data 1 and 2 between 2018 and 2019. The $\mathrm{N}_{\mathrm{C}}$ dilution curves for the two spring cultivars (TC19 and ND19) were calibrated using twenty data points (LDM range from 1.11 to $4.25 \mathrm{t} \mathrm{ha}^{-1}$ ), during the vegetative growth stages of spring maize (Fig. 3a). The $\mathrm{N}_{\mathrm{c}}$ values decreased with an increase in LDM. The coefficients of equations determination of TC19 and ND19 cultivars were 0.90 and $0.95(P<0.01)$, respectively (Fig. 3a).

TC19: $\mathrm{N}_{\mathrm{C}}=3.41 \mathrm{LDM}^{-0.22}$ (4)

ND19: $\mathrm{N}_{\mathrm{C}}=3.28 \mathrm{LDM}^{-0.27}$ (5) 
The coefficients of the two $\mathrm{N}_{\mathrm{c}}$ curves for TC19 and ND19 (Fig. 3a) were analyzed based on the method described by Mead and Curnow [30]. We did not observe a significant difference $\left(\mathrm{t}_{\text {slope }}=0.548<\mathrm{t}(0.05\right.$, $20)=2.086$, and $\left.t_{\text {intercept }}=0.435<t(0.05,20)=2.086\right)$ at the $95 \%$ confidence level. Therefore, the $N_{c}$ curves of the two spring cultivars were combined and fitted to obtain the unified $\mathrm{N}_{\mathrm{c}}$ curve of maize under drip-irrigated (Fig. 3b). However, we could not obtain a robust $\mathrm{N}_{\mathrm{c}}$ curve the early growth stages (V4) of spring maize, since LNC does not change significantly with the increase of the low LDM. There is no obvious competition between plants' utilization of water, fertilizer, light, and other resources. When LDM increases, LNC does not be significantly reduced. The low LDM data were acquired in the early growth stage of maize when the plants were very small. In this study, the $\mathrm{N}_{\mathrm{c}}$ curves were not applied to the early growth of maize. Instead, a minimum LNC value (3.31\%) was defined for the non-N-limiting group, while a maximum LNC value (3.19\%) for the N-limiting groups. The LNC value of $3.25 \%$ was defined as the constant leaf $N_{c}$ value for the early growth stage of maize (Fig. 3b), when LDM $<1.11$ t ha $^{-1}$ (Fig. 3b). Therefore, the $\mathrm{N}_{\mathrm{c}}$ curve can be described as follows:

$$
\begin{cases}\mathrm{N}_{\mathrm{c}}=3.33 \mathrm{LDM}^{-0.24} & \mathrm{LDM} \geq 1.11 \\ \mathrm{~N}_{\mathrm{c}}=3.25 \% & \mathrm{LDM}<1.11\end{cases}
$$

\section{Validation Of The $\mathbf{N}$ Curve}

The LDM based $\mathrm{N}_{\mathrm{c}}$ model was validated using data from a one-year independent experiment 3 in two spring maize cultivars (TC19 and ND19), in $2020(n=72)$ (Fig. 4). The results showed that the non-Nlimiting and $\mathrm{N}$-limiting group data were located above and below the $\mathrm{N}_{c}$ curve, respectively. The $\mathrm{N}_{c}$ curve effectively distinguished the $\mathrm{N}$-limiting from the non-N-limiting groups in the independent experimental data and was not affected by the growing seasons, growth stages, and cultivars. Therefore, the calibrated LDM based $\mathrm{N}_{\mathrm{C}}$ curve in this study can be applied for evaluating and diagnosing the $\mathrm{N}$ nutritional status of spring maize.

\section{Changes Of Nni Values Under Various $\mathbf{N}$ Levels}

There was substantial variation in NNI between different $\mathrm{N}$ levels, cultivars growing seasons and stages (Fig. 5). NNI increased with an increase of N application. NNI values of TC19 and ND19 ranged between 0.61 to 1.45 and 0.60 to 1.32 , respectively (Fig. $5 a, b)$ in 2018 , and between 0.55 to 1.29 and 0.62 to 1.37 (Fig. 5c, d) in 2019, respectively. Furthermore, the NNI values were NO, N1, and N2 rates less than 1.0 in 2018 and 2019, which indicated that LNC was low and that the N fertilizer application rates were insufficient. However, the NNI values in N4 and N5 rates in 2018 and 2019 were greater than 1.0, which indicated that LNC was high and that the $\mathrm{N}$ fertilizer rates were excessively applied. NNI values in the N3 
rate were around 1.0, which indicated the $\mathrm{N}$ application dose of $270 \mathrm{~kg} \mathrm{ha}^{-1}$ not only ensured the accumulation of LDM but also prevented $\mathrm{N}$ extravagant absorption.

\section{Relationships Between Nni And Rldm}

The correlation between NNI and RLDM was studied with data from experiments 1 and 2, obtained in 2018 and 2019. NNI and RLDM showed a significant linear correlation at different growth stages, and RLDM increased with an increase in NNI (Fig. 6). The coefficients of determination from V4 to R1 were $0.84,0.89,0.83,0.87,0.65$ and 0.67 , respectively.

\section{Discussion}

\section{Critical Nitrogen Dilution Curves Compared with Other Crops}

Precise estimation of crops $\mathrm{N}$ nutritional status is essential for improving their $\mathrm{N}$ utilization efficiency. The $\mathrm{N}_{\mathrm{C}}$ has been broadly utilized for diagnosing crops $\mathrm{N}$ nutritional status [31]. In the present study, the $\mathrm{N}_{\mathrm{C}}$ value in the vegetative growth stage of spring maize gradually decreased with increased LDM (Fig. 3a), and this is consistent with that reported in rice (either the whole plant or the specific organ) $[14,25]$ and wheat $[18,26]$. The LNC based $\mathrm{N}_{\mathrm{C}}$ dilution curve of spring maize under drip irrigation consisted of two parts: when LDM $<1.11 \mathrm{t} \mathrm{ha}^{-1}$, the $\mathrm{N}_{\mathrm{c}}$ value was defined as $3.25 \%$, and when LDM $\geq 1.11 \mathrm{t} \mathrm{ha}^{-1}$, the $\mathrm{N}_{\mathrm{C}}$ curve was defined as $3.33 * \mathrm{LDM}^{-0.24}$ (Fig. 3b). Due to the little individual plants and minimal dry matter accumulation in leaves before the early growth stages (V4) of spring maize, there was no obvious competition for water, fertilizer, light, and other resources. The increase in LDM did not significantly reduce $L N C$. Therefore, the leaf $\mathrm{N}_{\mathrm{C}}$ value was relatively stable in the early growth stage of spring maize. After the jointing stage (V6), leaf area index and leaf number increased, stalk growth occurred due to the phenomenon of shading, and this led to $\mathrm{N}$ dilution [32].

From a mathematical view, parameter a means the LNC when LDM equals to $1.0 \mathrm{t} \mathrm{ha}^{-1}$ and represents the inherent $\mathrm{N}$ demand characteristics of the spring maize at the early growth stage. Parameter $b$ indicates the change in LNC with LDM, and its value is determined by the proportional ratio between leaf $\mathrm{N}$ absorption and dry matter. In the present study, the value of parameter $b(0.24)$ was less than that of the $\mathrm{N}_{\mathrm{C}}$ dilution curve based on PDM for maize [33] (Fig. 3b). Low parameter $b$ means that the leaf $\mathrm{N}$ dilution process is slow. The differences in PDM and LDM curves were mainly reflected in the calibrated model. Based on the $\mathrm{N}_{\mathrm{c}}$ curve determined by LDM, the leaves were regarded as the central locations of crop growth. The $\mathrm{N}$ absorbed by the crop met the leaf growth, photosynthesis, and respiration needs, and led to a slow decline in LNC $[34,35]$. For PDM based $\mathrm{N}_{\mathrm{C}}$ curve, the stem $\mathrm{N}$ concentration was lower than 
that of leaf during the vegetative growth stages, while the dilution rate was lower than that of the stem [21], which was related to the leaf being the main organ of photosynthesis, and requires a certain $\mathrm{N}$ concentration to ensure efficient photosynthesis and yield formation [36]. Additionally, the $\mathrm{N}_{\mathrm{c}}$ dilution curve $b$ value of spring maize leaves under drip irrigation was higher than the reported $\mathrm{N}_{c}$ dilution curve $b$ value of winter wheat and rice leaves $(0.15,0.22)[25,26]$ (Fig. 7). The $b$ value of $N_{c}$ curve varies with crop types.

\section{Application And Feasibility Analysis Of Lnc Based N Curve}

The main purpose of calibrating the $\mathrm{N}_{\mathrm{C}}$ dilution curve was to assess the $\mathrm{N}$ nutritional status of maize through agronomic research methods in this study. This scientific $\mathrm{N}$ application technology can reduce the cost of production and anthropogenic $\mathrm{N}$ pollution [37]. The $\mathrm{N}_{\mathrm{c}}$ curve provides an alternative to assess the $\mathrm{N}$ nutritional status in the growth stage of maize under drip irrigation. Previous studies indicate that only the LDM and LNC of the maize can reflect its $\mathrm{N}$ nutritional status using the $\mathrm{N}_{\mathrm{c}}$ curve. For example, when LNC values were on the $\mathrm{N}_{\mathrm{c}}$ curve, which indicated that the $\mathrm{N}$ application rate was optimum; $\mathrm{LNC}$ values ranged between $N_{\text {min }}$ and $N_{c}$, indicating a deficiency in the $N$ application rate. LNC values were between $\mathrm{N}_{\mathrm{c}}$ and $\mathrm{N}_{\text {max }}$, which indicated that excessive $\mathrm{N}$ was applied. The calibrated $\mathrm{N}_{\mathrm{c}}$ curve can be used to distinguish the $\mathrm{N}$ deficiency from the surplus states of crops, and the Crop-Syst model [38] is used to calculate the $\mathrm{N}$ demand with the assistance of the $\mathrm{N}_{c}$ curve [39].

$\mathrm{NNI}$ can serve as an ideal indicator to diagnose $\mathrm{N}$ nutritional status of crops [22]. In this study, the NNI values of leaves in the two spring maize cultivars ranged between 0.55 and 1.45 under different $\mathrm{N}$ rates (Fig. 5). The NNI value per $\mathrm{N}$ rate was lowest in $\mathrm{V} 12$, which increased with an increase in $\mathrm{N}$ fertilizer application rate from V12 to R1 stage. This was associated with the vigorous spring maize growth and development in V12 to R1 stage, the high absolute and relative quantities of nutrients required by maize, and the high absorption rate during this stage [40]. Secondly, the NNI was recovered in R1(Fig. 5), which was linked to the $\mathrm{N}$ status of spring maize converting from vegetative growth to reproductive growth stage, and the demand for $\mathrm{N}$ fertilizer was not as urgent as that in V12 (Fig. 5). This indicates that the $\mathrm{N}$ status of spring maize can be affected by the amount of $\mathrm{N}$ fertilizer application at different fertilization periods, which NNI can confirm, and this was in line with the previous reports [41]. This conclusion could be adopted to obtain a quantitative $\mathrm{NNI}$ and to diagnose $\mathrm{N}$ deficiency in spring maize with sufficient efficiency and effectiveness.

The $\mathrm{N}_{\mathrm{c}}$ dilution curve of crops are calibrated under different $\mathrm{N}$ rates in most studies, and other conditions are found to be relatively suitable. However, crops are subjected to stress caused by different factors in real agricultural production. For example, severe drought stress severely affected the final yield of spring wheat during the growth stage in Northern China [42]. Previous studies show that $\mathrm{N}_{\mathrm{c}}$ dilution curves and NNI values of crops under drought stress are lower than normal [43]. This can be associated with the lack of water, which limits plant growth and causes a reduction in dry matter, thus caused a decrease of $\mathrm{N}$ 
accumulation. Besides, because water content has a close relationship with the $\mathrm{N}$ availability, water deficiency reduces the bio-available $\mathrm{N}$ in soils, thus caused a decrease in the soil $\mathrm{N}$ supply capacity [44]. Therefore, the crop $\mathrm{N}$ deficiency was seen when NNI was lower than 1.0, and topdressing with $\mathrm{N}$ was needed. Besides water, the interaction between other elements such as phosphorus and potassium with $\mathrm{N}$ also affected the $\mathrm{N}$ status of crops [45]. Therefore, clarifying the factors affecting the $\mathrm{N}_{\mathrm{c}}$ dilution curve of crops under different conditions is of great significance for its application, and the use of $\mathrm{NNI}$ in accurately diagnosing crops $\mathrm{N}$ nutritional status.

\section{Conclusion}

LNC decreases with an increase in LDM, and further increases with the $\mathrm{N}$ application rates during the early growth stages of spring maize under drip irrigation. A calibrated maize $\mathrm{N}_{\mathrm{c}}$ model is reported in this study, in two cultivars with different $\mathrm{N}$ rates. The $\mathrm{N}_{\mathrm{c}}$ dilution curve equation used is $\mathrm{N}_{\mathrm{c}}=3.25 \%$, when LDM $<1.11 \mathrm{t} \mathrm{ha}^{-1}$, and $\mathrm{N}_{\mathrm{C}}=3.33 \mathrm{LDM}^{-0.24}$ when LDM $\geq 1.11 \mathrm{t} \mathrm{ha}^{-1}$. The calibrated $\mathrm{N}_{\mathrm{C}}$ curve effectively distinguishes the $\mathrm{N}$-limiting from the non-N-limiting groups based on LDM, and the curve is not independent with the cultivars, growing seasons and stages. NNI is utilized to assess the $\mathrm{N}$ nutritional state of maize plants. NNI of N3 rate $\left(270 \mathrm{~kg} \mathrm{ha}^{-1}\right)$ is considered to be closest to 1.0 , and maximum LDM can be obtained with the $\mathrm{N} 3$ rate. $\mathrm{NNI}$ is, therefore, significantly positively correlated with RLDM.

Therefore, the $\mathrm{N} 3$ rate $\left(270 \mathrm{~kg} \mathrm{ha}^{-1}\right)$ may be used as the reference of $\mathrm{N}$ application for spring maize under drip irrigation, and water and fertilizer integration in Northwest China.

\section{Declarations}

The authors are grateful to the members of Ma Kun's laboratory for constructive suggestions. We also appreciate the editor and reviewers for their valuable suggestions and comments to improve this scientific study.

\section{Authors' contributions}

BJ conceived the project and co-wrote the manuscript. JPF, HFL and ZHL collected training data, models and co-wrote the manuscript. YL, XW,YQZ, JZM and HZ collected training data and models. All authors read and approved the final manuscript.

\section{Funding}

The financial support of the Natural Science Foundation of Ningxia (2020AAC02012, 2021AAC03025) is acknowledged.

\section{Ethics approval and consent to participate}

Not applicable. 


\section{Consent for publication}

Not applicable.

\section{Competing interests}

The authors declare that they have no competing interests.

\section{Author details}

1 School of Agriculture, Ningxia University, Yinchuan 750021, China

\section{References}

1. Erisman JW, Van Grinsven H, Leip A, Mosier A, Bleeker A. Nitrogen and biofuels; an over view of the current state of knowledge. Nutr Cycl Agroecosys. 2010; 86: 211-223.

2. Pan JX, Meng QF, Chen RY, Cui ZL, Chen XP. In-Season Nitrogen Management to Increase Grain Yields in Maize Production. Agron J. 2017; 109: 2063-3071.

3. Zaman M, Blennerhassett JD. Effects of the different rates of urease and nitrification inhibitors on gaseous emissions of ammonia and nitrous oxide, nitrate leaching and pasture production from urine patches in an intensive grazed pasture system. Agr Ecosyst Environ. 2010; 136: 236-246.

4. Ata-Ul-Karim ST, Zhu Y, Liu XJ, Cao Q, Tian YC, Cao WX. Comparison of different critical nitrogen dilution curves for nitrogen assessment in rice. Sci Rep. 2017a; 7: 42679.

5. Zhao B. Determining of a critical dilution curve for plant nitrogen concentration in winter barley. Field Crop Res. 2014; 96: 224-234.

6. Yoon CG, Kwun SK, Ham JH. Effects of treated sewage irrigation on paddy rice culture and its soil. Irrig Drain. 2001; 50: 227-236.

7. Zhou W, Yang ZP, Wang T, Fu Y, Chen Y, Hu BH, et al. Environmental compensation effect and synergistic mechanism of optimized nitrogen management increasing nitrogen use efficiency in indica hybrid rice. Front Plant Sci. 2019; 10: 245.

8. Ata-UI-Karim ST, Zhu Y, Lu XJ, Cao Q, Tian YC, Cao WX. Estimation of nitrogen fertilizer requirement for rice crop using critical nitrogen dilution curve. Field Crop Res. 2017b; 32-40.

9. Miao YX, Stewart BA, Zhang FS. Long-term experiments for sustainable nutrient management in China. A review. Agron Sustain Dev. 2011; 31: 397-414.

10. Zhang K, Yuan ZF, Yang TC, Lu LL, Cao Q, Tian YC, et al. Chlorophyll meter-based nitrogen fertilizer optimization algorithm and nitrogen nutrition index for in-season fertilization of paddy rice. Agron $\mathrm{J}$. 2020: 1-13.

11. Grohs DS, Bredemeier C, Mundstock CM, Poletto N. Model for yield potential estimation in wheat and barley using the GreenSeeker sensor. Eng Agr. 2009; 29: 101-112. 
12. Schlemmer M, Gitelson A, Schepers J, Ferguson R, Peng Y, Shanahan J, et al. Remote estimation of nitrogen and chlorophyll contents in maize at leaf and canopy levels. Int J Appl Earth Obs. 2013; 25: 47-54.

13. Elsayed S, Barmeier G, Schmidhalter U. Passive Reflectance Sensing and Digital Image Analysis Allows for Assessing the Biomass and Nitrogen Status of Wheat in Early and Late Tillering Stages. Front Plant Sci. 2018; 9: 1478.

14. Ata-Ul-Karim ST, Xia Y, Liu XJ, Cao WX, Zhu Y. Development of critical nitrogen dilution curve of Japonica rice in Yangtze River Reaches. Field Crop Res. 2013; 149: 149-158.

15. Greenwood DJ, Gastal F, Lemaire G, Draycott A, Millard P, Neeteson JJ. Growth rate and percentage nitrogen of field grown crops: theory and experiments. Ann Bot. 1991; 67: 181-190.

16. He ZY, Qiu XL, Ata-UI-Karim ST, Li YD, Liu XJ, Cao Q, et al. Development of a critical nitrogen dilution curve of double cropping rice in south China. Front Plant Sci. 2017; 8: 638.

17. Huang SY, Miao YX, Cao Q, Yao YK, Zhao GM, Yu WF, et al. A new critical nitrogen dilution curve for rice nitrogen status diagnosis in Northeast China. Pedosphere. 2018; 28: 814-822.

18. Yin MH, Li YN, Xu LQ, Shen SL, Fang H. Nutrition diagnosis for nitrogen in winter wheat based on critical nitrogen dilution curves. Crop Sci. 2018; 58: 416-420.

19. Ziadi N, Belanger G, Claessens A, Lefebvre L, Cambouris AN, Tremblay N, et al. Determination of a critical nitrogen dilution curve for spring wheat. Agron J. 2010; 102: 241-250.

20. Giletto CM, Echeverría HE. Critical nitrogen dilution curve for processing potato in Argentinean humid pampas. Am J Potato Res. 2012; 89: 102-110.

21. Yue SC, Sun F, Meng QF, Zhao RF, Li F, Chen XP, et al. Validation of a critical nitrogen curve for summer maize in the north China plain. Pedosphere. 2014; 24: 76-83.

22. Zhao B, Ata-UI-Karim ST, Liu ZD, Ning DF, Xiao JF, Liu ZG, et al. Development of a critical nitrogen dilution curve based on leaf dry matter for summer maize. Field Crop Res. 2017; 208: 60-68.

23. Liang XG, Zhang ZL, Zhou LL, Shen S, Gao Z, Zhang L, et al. Localization of maize critical n curve and estimation of NNI by Chlorophyll. Int J Plant Prod. 2018; 12: 85-94.

24. Kage $\mathrm{H}$, Alt C, Stützel $\mathrm{H}$. Nitrogen concentration of cauliflower organs as determined by organ size, $\mathrm{N}$ supply, and radiation environment. Plant Soil. 2002; 246: 201-209.

25. Yao X, Ata-Ul-Karim ST, Zhu Y, Tian Y, Liu X, Cao W. Development of critical nitrogen dilution curve in rice based on leaf dry matter. Eur J Agro. 2014a; 55: 20-28.

26. Yao X, Zhao B, Tian YC, Liu XJ, Ni J, Cao WX, et al. Using leaf dry matter to quantify the critical nitrogen dilution curve for winter wheat cultivated in eastern China. Field Crop Res. 2014b; 159: 3342.

27. Nelsonand DW, Sommers LE. A simple digestion procedure for estimation of total nitrogen in soils and sediments. J Environ Qual. 1972; 1: 423-425.

28. Justes E, Mary B, Meynard JM, Machet JM, Thelier-Huche L. Determination of a critical nitrogen dilution curve for winter wheat crops. Ann Bot. 1994; 74: 397-407. 
29. Plénet $D$, Lemaire G. Relationships between dynamics of nitrogen uptake and dry matter accumulation in maize crops. Determination of critical N concentration. Plant Soil. 2000; 216: 6582.

30. Mead R, Curnow RN, Hasted AM. Statistical Methods in Agriculture and Experimental Biology. Ed G. Mead (New York: Champan and Hall), 1993, 157-163.

31. Wang Y, Shi P, Zhang G, Ran J, Wang DJ. A critical nitrogen dilution curve for japonica rice based on canopy images. Field Crop Res. 2017; 198: 93-100.

32. Yue SC, Meng QF, Zhao RF, Li F, Chen XP, Zhang FS, et al. Critical nitrogen dilution curve for optimizing nitrogen management of winter wheat production in the North China plain. Agron J. 2012; 104: 523-529.

33. Li WJ, He P, Jin JY. Critical nitrogen curve and nitrogen nutrition index for spring maize in North-East China. J Plant Nutr. 2012; 35: 1747-1761.

34. Bannister P. Observation on water potential and drought-resistance of trees and shrubs after a period of summer drought around Dunedin, New Zealand. New Zeal J Bot. 1986; 24: 387-392.

35. Wang ZJ, Wang JH, Zhao CJ, Zhao M, Huang WJ, Wang CZ. Vertical distribution of nitrogen in different layers of leaf and stem and their relationship with grain quality of winter wheat. J Plant Nutr. 2005; 28: 73-91.

36. Zhao B, Ata-UI-Karim ST, Duan AW, Liu ZD, Wang XL, Xiao JF, et al.Determination of critical nitrogen concentration and dilution curve based on leaf area index for summer maize. Field Crop Res. 2018a; 228: 195-203.

37. Arash R, Ali R, Hamed E, Maryam V. Determination of critical nitrogen dilution curve based on canopy cover data for summer maize. Commun Soil Sci Plan. 2020; 51: 2244-2256.

38. Stockle CO, Martin S, Campbell GS. CropSyst, a cropping systems simulation model: Water/nitrogen budgets and crop yield. <background-color:\#CCFF99;uvertical-align:super;>Agr Syst</backgroundcolor:\#CCFF99;uvertical-align:super;>. 1994; 46: 335-359.

39. Stockle CO, Debaeke P. Modeling crop nitrogen requirements: A critical analysis. Eur J Agro. 1997; 7 : 161-169.

40. Zhao B, Ata-UI-Karim ST, Liu ZD, Zhang JY, Xiao JF, Liu ZG, et al. Simple assessment of nitrogen nutrition index in summer maize by using chlorophyll meter readings. Front Plant Sci. 2018b; 9: 11.

41. Lemaire G, Marie-Helene J, Grancois F. Diagnosis tool for plant and crop N status in vegetative stage: theory and practices for crop N management. Eur J Agr. 2008; 28: 614-624.

42. Ji XM, Shiran B, Wan JL, Lewis DC, Jenkins CLD, Condon AG, et al. Importance of preanthesis anther sink strength for maintenance of grain number during reproductive stage water stress in wheat. Plant Cell Environ. 2010; 33: 926-942.

43. Hoogmoed M, Neuhaus A, Noack S, Sadras VO. Benchmarking wheat yield against crop nitrogen status. Field Crop Res. 2018; 153-163. 
44. Kunrath TR, Lemaire G, Sadras VO, Gastal F. Water use efficiency in perennial forage species: Interactions between nitrogen nutrition and water deficit. Field Crop Res. 2018; 222: 1-11.

45. Duncan EG, O'sullivan CA, Roper MM, Palta J, Whisson K, Peoples M. Yield and nitrogen use efficiency of wheat increased with root length and biomass due to nitrogen, phosphorus, and potassium interactions. J Plant Nutr Soil Sci. 2018; 181: 364-373.

\section{Figures}

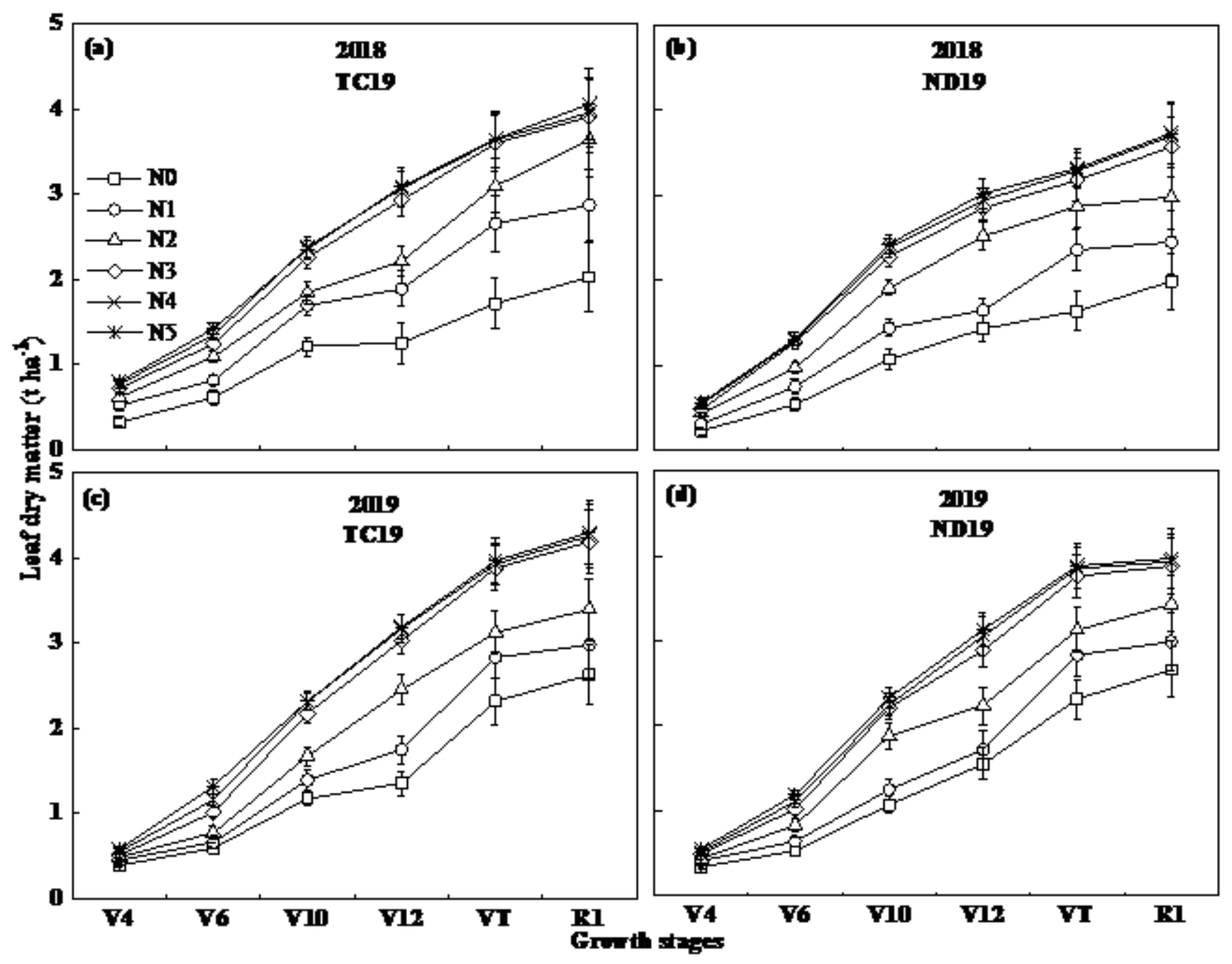

Figure 1

Changes in maize LDM at various growth stages under different nitrogen $(\mathrm{N})$ fertilizer application dosages in two years of experimental data (a: 2018 TC19, b: 2019 TC19, c: 2018 ND19, d: 2019 ND19). 


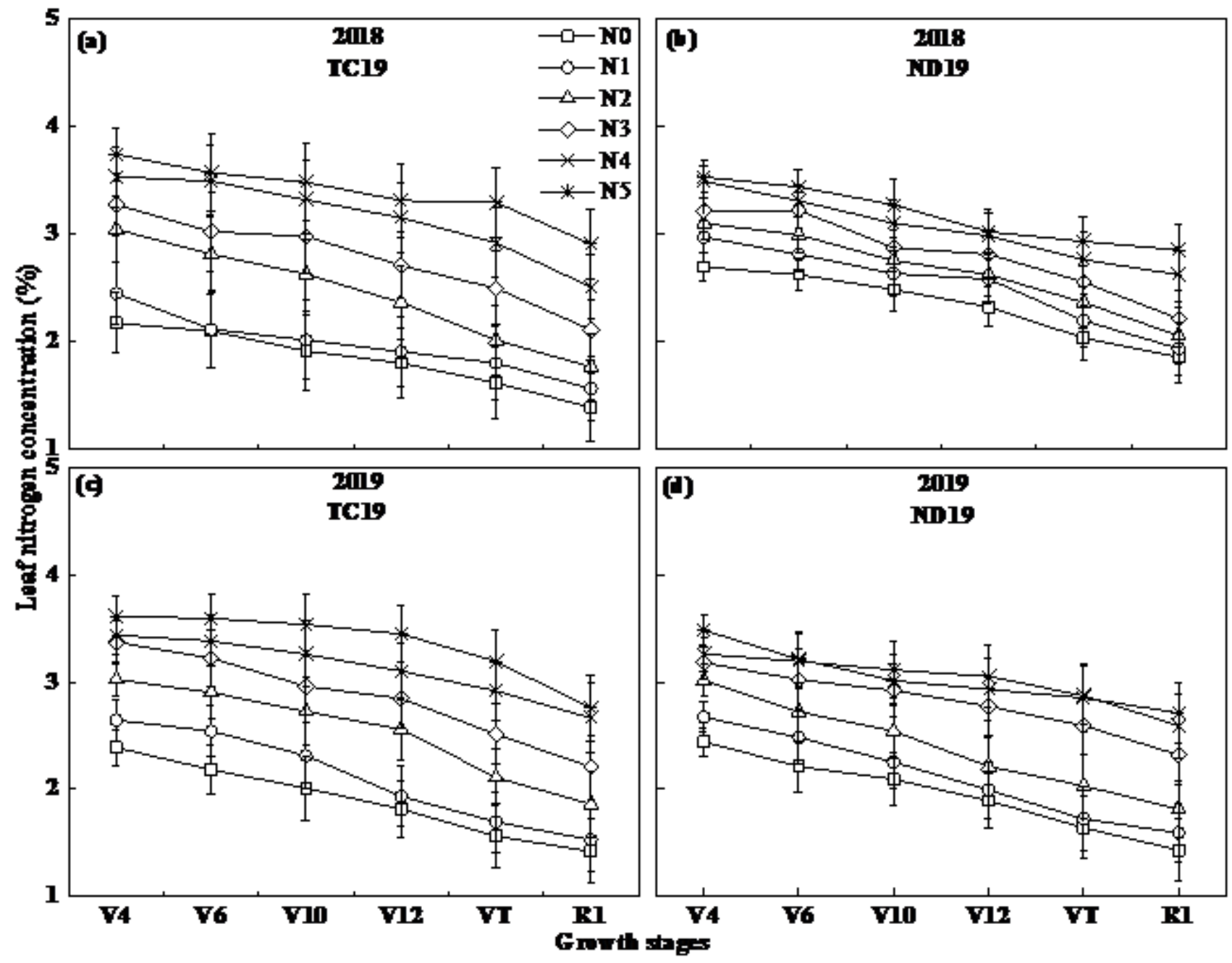

Figure 2

Changes in maize LNC at various growth stages under different $\mathrm{N}$ fertilizer application dosages in two years of experimental data (a: 2018 TC19, b: 2018 ND19 c:2019 TC19, d: 2019 ND19). 


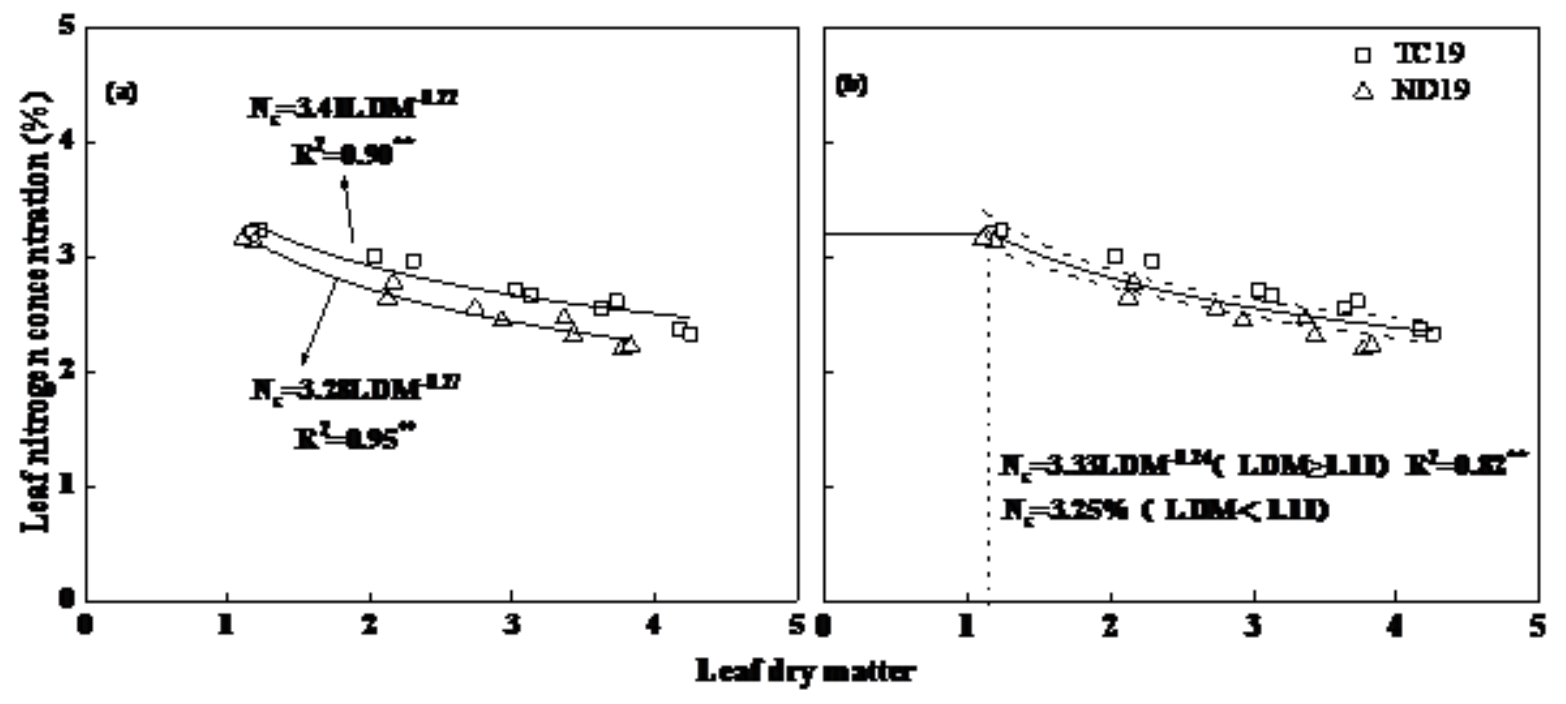

Figure 3

The leaf Nc for two maize cultivars (TC19 and ND19) in 2018 and 2019. (a: The Nc dilution curves for two spring cultivars (TC19 and ND19) calibrated using twenty data points, b: the curves of two spring cultivars combined and fitted to obtain the unified Nc curve of maize). ** indicates significant difference at $P<0.01$. 


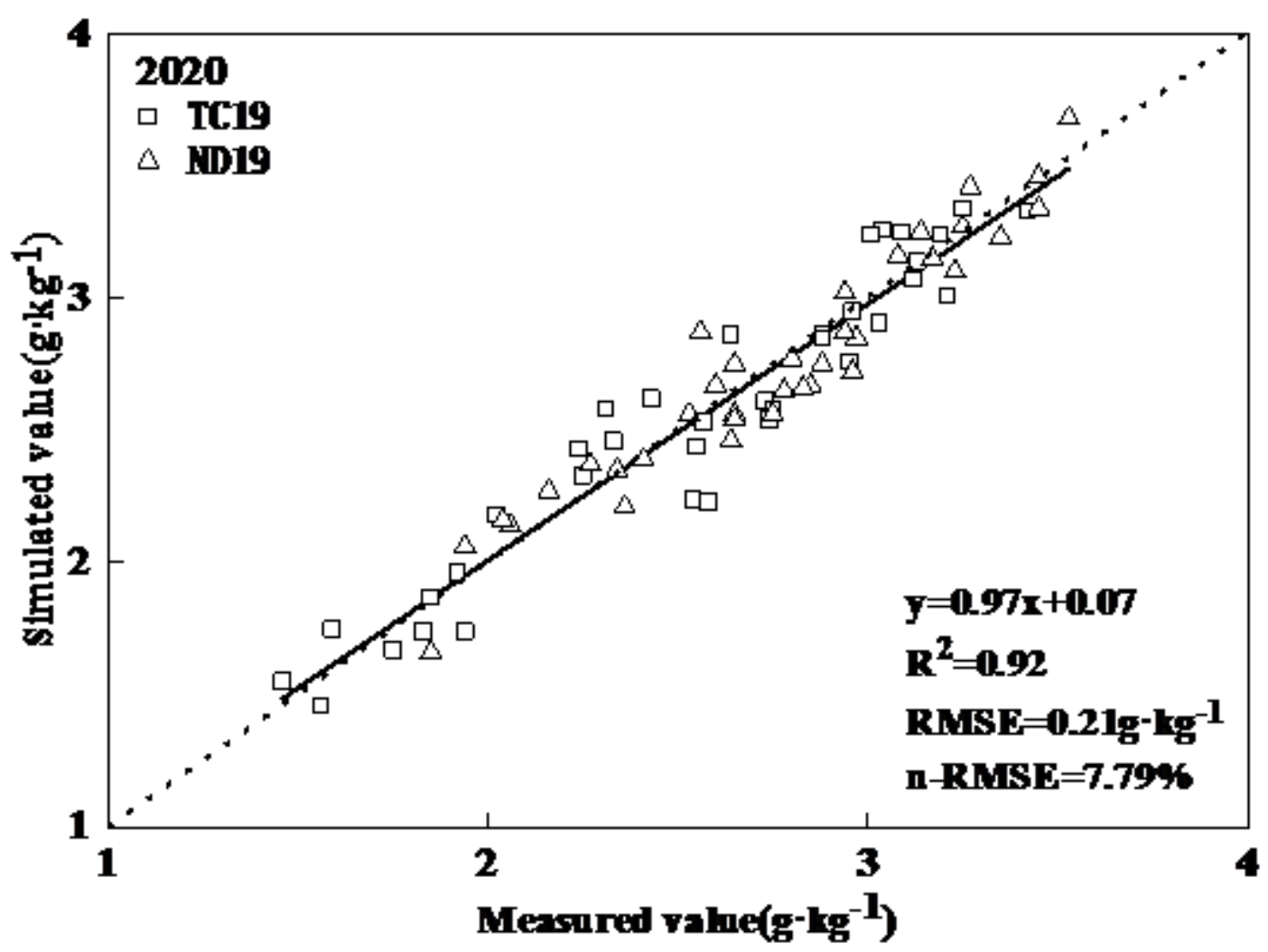

Figure 4

Validation of the established leaf Nc dilution curve. The data were collected from an independent experiment using two maize cultivars (TC19 and ND19), which was conducted in 2020. 


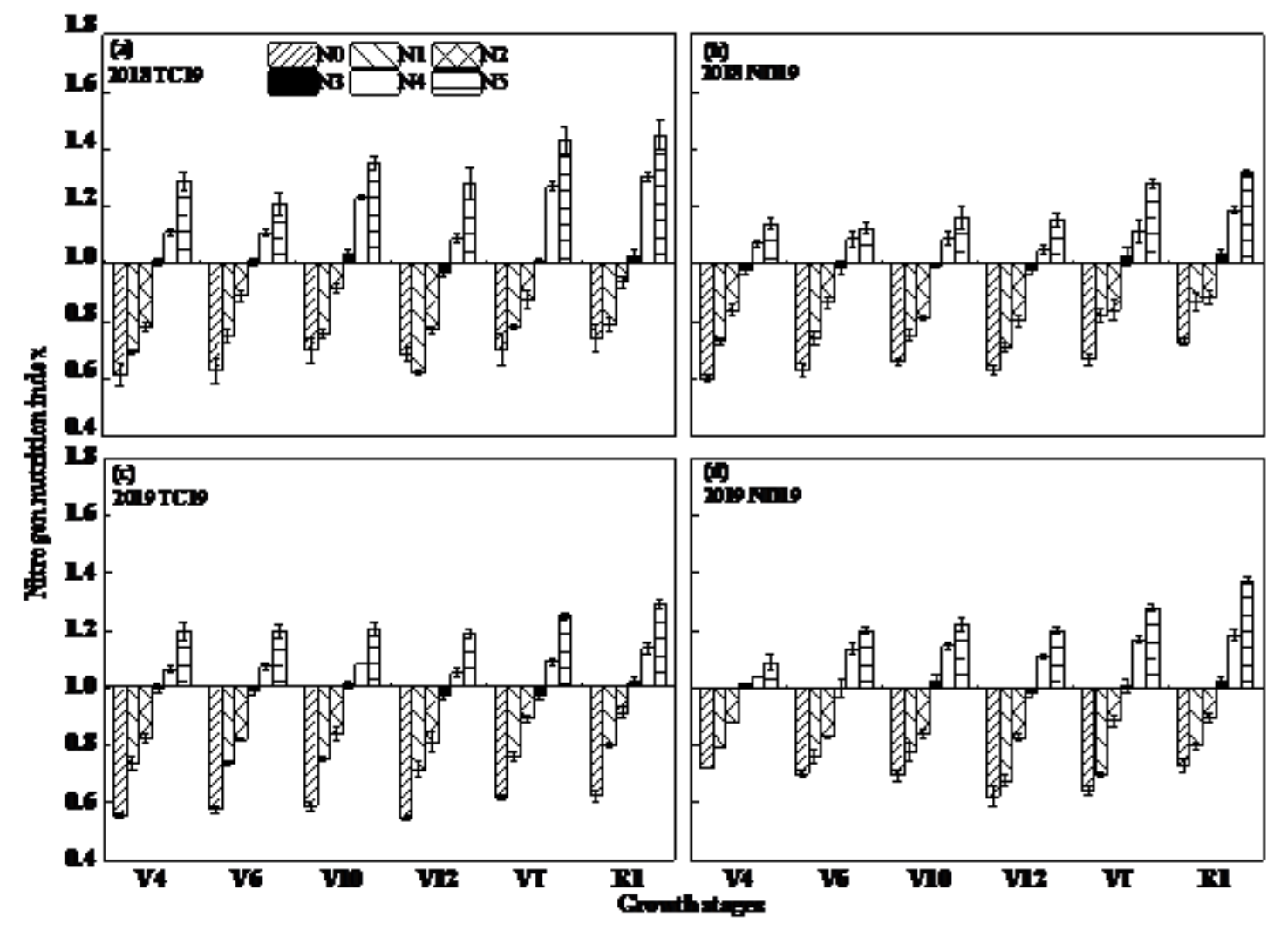

Figure 5

Dynamic changes in the $\mathrm{N}$ nutrition index (NNI) for two varieties (TC19 and ND19) at various growth stages (V4 to R1) under different N application dosages. (a: 2018 TC19, b: 2018 ND19, c: 2019 TC19, d: 2019 ND19). 


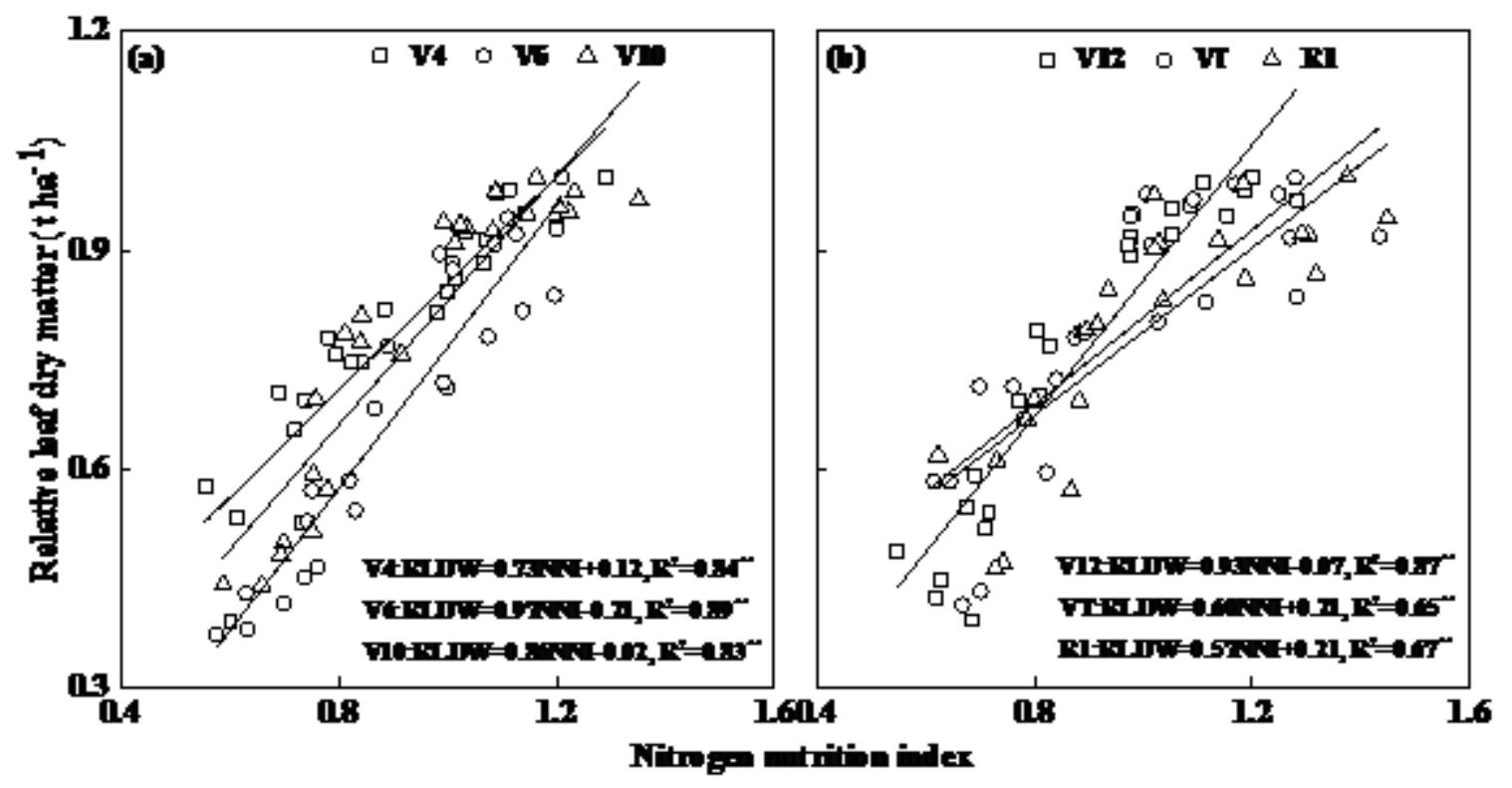

Figure 6

The correlation between NNI with relative leaf dry matter (RLDM) for two maize cultivars (TC19 and ND19) at various growth stages (V4 to R1) during the 2018 and 2019 growing seasons. (a: V4, V6, and V10 stages of maize; b: V12, VT and R1 stages of maize). 

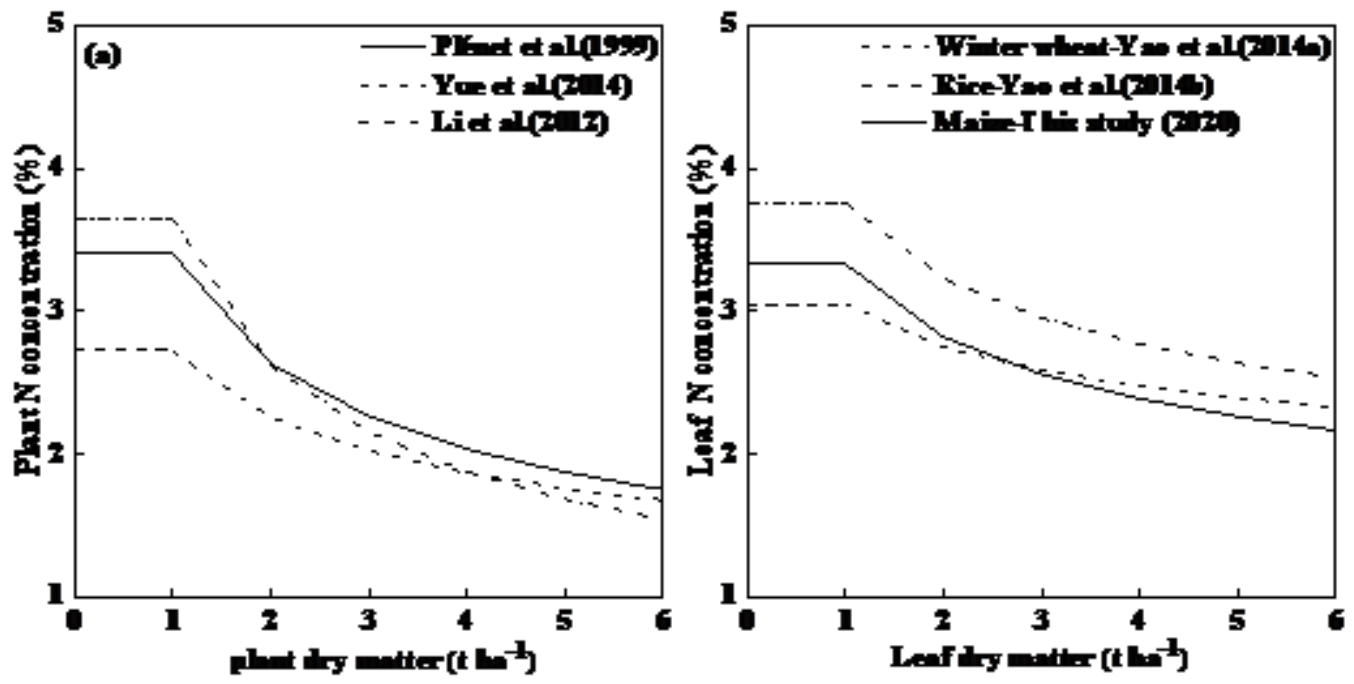

Figure 7

Comparison of LDM based Nc curves in different crops. 